\title{
Targeted alpha therapy using a novel CD70 targeted thorium-227 conjugate in in vitro and in vivo models of renal cell carcinoma
}

\author{
Urs B. Hagemann ${ }^{1}$, Dessislava Mihaylova ${ }^{1}$, Steinar R. Uran ${ }^{1}$, Joergen Borrebaek ${ }^{1}$, \\ Derek Grant ${ }^{1}$, Roger M. Bjerke ${ }^{1}$, Jenny Karlsson ${ }^{1}$ and Alan S. Cuthbertson ${ }^{1}$ \\ ${ }^{1}$ Thorium Conjugate Research, Bayer AS, Oslo, Norway \\ Correspondence to: Urs B. Hagemann, email: urs.hagemann@bayer.com \\ Keywords: targeted alpha therapy (TAT), alpha particles, radioimmunotherapy, thorium-227, renal cell carcinoma \\ Received: January 25, $2017 \quad$ Accepted: March 13, $2017 \quad$ Published: April 07, 2017 \\ Copyright: Hagemann et al. This is an open-access article distributed under the terms of the Creative Commons Attribution License \\ 3.0 (CC BY 3.0), which permits unrestricted use, distribution, and reproduction in any medium, provided the original author and \\ source are credited.
}

\section{ABSTRACT}

The cell surface receptor CD70 has been previously reported as a promising target for B-cell lymphomas and several solid cancers including renal cell carcinoma. We describe herein the characterization and efficacy of a novel CD70 targeted thorium-227 conjugate (CD70-TTC) comprising the combination of the three components, a CD70 targeting antibody, a chelator moiety and the short-range, high-energy alpha-emitting radionuclide thorium-227 $\left({ }^{227} \mathrm{Th}\right)$. In vitro analysis demonstrated that the CD70-TTC retained binding affinity to its target and displayed potent and specific cytotoxicity compared to an isotype control-TTC. A biodistribution study in subcutaneous tumorbearing nude mice using the human renal cell carcinoma cell line 786-0 demonstrated significant uptake and retention with $122 \pm 42 \%$ of the injected dose of ${ }^{227}$ Th per gram ( $\% \mathrm{ID} / \mathrm{g})$ remaining in the tumor seven days post dose administration compared to only $3 \% \mathrm{ID} / \mathrm{g}$ for the isotype control-TTC. Tumor accumulation correlated with a dose dependent and statistically significant inhibition in tumor growth compared to vehicle and isotype control-TTC groups at radioactivity doses as low as $50 \mathrm{kBq} / \mathrm{kg}$. The CD70TTC was well tolerated as evidenced by only modest changes in hematology and normal gain in body weight of the mice. To our knowledge, this is the first report describing molecular targeting of CD70 expressing tumors using a targeted alpha-therapy (TAT).

\section{INTRODUCTION}

The principle of targeted alpha therapy in oncology is based on the specific delivery of high linear energy transfer (LET) alpha-particle emitting radionuclides to tumor-associated antigens $[1,2]$. Several alpha radionuclides including bismuth- $213\left({ }^{213} \mathrm{Bi} ; \mathrm{t}_{1 / 2}=46\right.$ $\mathrm{min})$, astatine-211 $\left({ }^{211} \mathrm{At} ; \mathrm{t}_{1 / 2}=7.2\right.$ hours), actinium-225 $\left({ }^{225} \mathrm{Ac} ; \mathrm{t}_{1 / 2}=9.9\right.$ days $)$ and thorium-227 $\left({ }^{227} \mathrm{Th} ; \mathrm{t}_{1 / 2}=\right.$ 18.7 days) combined with monoclonal antibodies have been previously reported in the literature to be highly efficacious, [3-8] lending further support for the continued clinical development of this new modality in cancer therapy. The short range of approximately 50 to $80 \mu \mathrm{m}$ in tissue of the alpha-particle has the potential to reduce offtarget toxicity compared to either external beam radiation therapy (EBRT) or the longer range beta-emitters such as yttrium-90 $\left({ }^{90} \mathrm{Y}\right)$ or lutetium-177 $\left({ }^{177} \mathrm{Lu}\right)$.
The recent approval of the first-in-class alpha radiopharmaceutical Xofigo (radium-223 dichloride, ${ }^{223} \mathrm{RaCl}_{2}$ ) for the treatment of metastatic castration resistant prostate cancer [3] by the Food and Drug Administration (FDA) has further increased the interest in new applications of TAT. Although the inherent bone-seeking accumulation of radium-223 $\left({ }^{223} \mathrm{Ra}\right)$ [4] allows for effective delivery to bone metastases, the lack of suitable chelating agents has so far impeded the development of ${ }^{223} \mathrm{Ra}$-based radioimmunoconjugates for broader applications in oncology [5]. In contrast, ${ }^{227} \mathrm{Th}$, the parent radionuclide of ${ }^{223} \mathrm{Ra}$, can be readily complexed to chelators such as the octadentate 3,2 hydroxypyridinone (3,2-HOPO) class [6]. These 3,2-HOPO chelators can be chemically conjugated to tumor-targeting monoclonal antibodies (mAbs) enabling radiolabeling at ambient temperature. Thorium-227 has a half-life of 18.7 days comparable to the blood half-life of therapeutic antibodies 
in humans and decays releasing a total of five high-energy alpha-particles, through the progeny cascade ${ }^{223} \mathrm{Ra},{ }^{219} \mathrm{Rn}$, ${ }^{215} \mathrm{Po},{ }^{211} \mathrm{~Pb},{ }^{211} \mathrm{Bi}$ and ${ }^{207} \mathrm{Tl}$ before reaching stable ${ }^{207} \mathrm{~Pb}$ [13]. The targeted thorium-227 conjugates (TTCs) have the potential to deliver highly potent alpha-particles to many different cancer types including both solid tumors and those of the lympho-hematopoietic system [7, 8].

The cell surface receptor CD70 and its ligand $\mathrm{CD} 27 \mathrm{~L}$ are members of the TNF ligand and receptor family [9]. In healthy individuals the ligand-receptor pair plays an important role in T-cell signalling and CD70 expression occurs transiently on activated T-cells, Tolllike receptor (TLR)-stimulated B-cells, mature dendritic cells (DCs), natural killer (NK) cells and on dendritic and epithelial cells of the thymic medulla [10-15]. The expression of CD70 and CD27L is highly regulated and limited to hematopoetic cells. CD70 is overexpressed on both $\mathrm{T}$ and $\mathrm{B}$-cell lymphomas with the highest incidence in diffuse large B-cell lymphoma (DLBCL) [16]. In solid tumors CD70 expression was first described in nasopharyngeal carcinoma potentially associated with Epstein-Barr virus (EBV) infection $[17,18]$. Subsequently, CD70 has been found to be overexpressed in renal cell carcinoma (RCC) [19-21], adenocarcinoma of pancreas and ovaries, breast and colon cancer, glioblastoma, laryngeal carcinoma and melanoma [15, 22, 23].

Due to its restricted and highly regulated expression on hematopoietic cells and healthy tissues as well as its internalizing properties, molecular targeting of CD70 positive tumors has been reported in several preclinical and clinical studies using antibodies inducing antibodydependent cell-mediated cytotoxicity (ADCC) and complement-dependent cytotoxicity (CDC) as well as antibody drug conjugates (ADCs). ARGX-110, a glycoengineered fully humanized monoclonal antibody was shown to induce potent ADCC upon binding to CD70 positive tumor cells [24]. The safety and tolerability profile of this antibody is currently being tested in a Phase 1 trial in patients with advanced malignancies (see clinical trial number NCT01813539). Further, the antibody SGN-70 has both inherent ADCC and CDC activity, demonstrating in vitro and in vivo efficacy in preclinical models of NonHodgkin Lymphoma (NHL) and multiple myeloma [21, 25]. The ADC, SGN-75, conjugated with the microtubule inhibitor auristatin, has also demonstrated potent activity in preclinical tumor models [26-29] and was the subject of a clinical trial in CD70-positive NHL and metastatic RCC patients (see clinical trial number NCT01015911). Further optimization led to SGN-CD70A in which the cytotoxic payload was the DNA cross-linking pyrrolobenzodiazepine (PBD) dimer [30]. This conjugate also demonstrated potent in vitro and in vivo activity, in models of NHL and RCC. SGN-CD70A is currently being tested in a Phase 1 study (see clinical trial number NCT02216890). Finally, the CD70targeted ADC, MDX-1203/BMS-936561, conjugated to a DNA cross-linking alkylating agent has also been tested in the clinic (see clinical trial number NCT00944905) showing both evidence of efficacy and an acceptable safety profile at doses up to $8 \mathrm{mg} / \mathrm{kg}$ in patients suffering from NHL and clear cell RCC [31].

We present herein for the first time a CD70 monoclonal antibody bearing the thorium-227 payload. The resulting CD70-targeted thorium-227 conjugate (CD70TTC) was found to possess both potent in vitro activity and demonstrated significant inhibition of tumor growth in vivo in the human renal cancer 786-O cell line derived xenograft model providing further support for the development novel radiotherapeutics for this important target.

\section{RESULTS}

\section{Generation and characterization of the CD70-TTC}

The CD70 targeting monoclonal antibody (IgG1) was conjugated with the 3,2-HOPO chelator through the $\varepsilon$-amino groups of lysine residues using water soluble carbodiimide as previously described $[6,8]$. The chelator to antibody ratio (CAR) was determined using sizeexclusion chromatography (SEC) by simultaneously monitoring the UV absorbance of the protein at 280 and $335 \mathrm{~nm}$. The resulting conjugate was determined to have a CAR of 1.0, a high-molecular weight (HMW) fraction of $2 \%$ and a monomeric peak of $98 \%$ as shown in Figure 1.

The binding properties of the CD70 antibody-chelator conjugate were compared to the naked CD70 antibody by ELISA using recombinant human $\mathrm{CD} 70 . \mathrm{EC}_{50}$ values of $0.24 \mathrm{nM}$ for the CD70 antibody and $0.3 \mathrm{nM}$ for the CD70 antibody-chelator conjugate were determined (Figure 2A) indicating that the binding potency was not impaired by conjugation. Similarly, binding to the CD70 expressing human renal cancer cell line 786-O was determined by FACS analysis as shown in Figure $2 \mathrm{~B}$ with $\mathrm{EC}_{50}$ values determined to be $0.39 \mathrm{nM}$ and $0.45 \mathrm{nM}$ for the CD70 antibody and CD70 antibody-chelator conjugate respectively.

Radiolabeling of the CD70 antibody-chelator conjugate was effected by simple addition of a solution of the conjugate to a vial containing a thorium-227 film at ambient temperature as described previously [8]. The resulting radiolabeled product was analyzed by instant thin-layer chromatography (iTLC) and radiochemical purity (RCP), defined as the fraction of bound ${ }^{227} \mathrm{Th}$ in the CD70-TTC compared to free ${ }^{227} \mathrm{Th}$, was determined to be consistently $\geq 95 \%$.

\section{In vitro cytotoxicity of the CD70-TTC}

In vitro cytotoxicity was performed using the CellTiter-Glo® assay on CD70-positive 786-O cells. Cells were exposed to the CD70-TTC at concentrations of 2 and $20 \mathrm{kBq} / \mathrm{ml}$ and to the isotype control-TTC at $20 \mathrm{kBq} / \mathrm{ml}$. Both conjugates were radiolabeled at a specific activity of $50 \mathrm{kBq} / \mu \mathrm{g}$. As presented in Figure 2C, exposure of cells to $\mathrm{CD} 70$-TTC demonstrated a dose-dependent reduction in 
cell viability over time. The effect was also highly specific to the CD70-TTC. These data demonstrate that CD70TTC induces potent and specific reduction in cell viability.

\section{Biodistribution of the CD70-TTC}

Biodistribution of the CD70-TTC was performed in 786-O tumor-bearing athymic mice bearing lesions with an average dimension of $200-300 \mathrm{~mm}^{3}$. The mice received an intravenous injection of CD70-TTC at a radioactive dose of $500 \mathrm{kBq} / \mathrm{kg}$ at a fixed protein dose of $0.36 \mathrm{mg} /$ $\mathrm{kg}$. To demonstrate specificity, a second group of animals were treated at the same radioactive and protein dose levels $(500 \mathrm{kBq} / \mathrm{kg} ; 0.36 \mathrm{mg} / \mathrm{kg})$ with the non-targeting isotype control-TTC. Immunohistochemical analysis of the tumors demonstrated high (3+) CD70 target expression and an average micro vessel density (MVD) of $324 \pm 55$ per $\mathrm{mm}^{2}$. Percentage of necrotic areas was in the range of not detectable to $14 \%$ of the analyzed tumor sections (Figure 3A and 3B). Autoradiography was performed on tumor sections after dose administration, the alpha-particle tracks were visualized as star-like formations as shown in Figure $3 \mathrm{C}$ and were not observed in tumor sections derived from the isotype control (Figure 3D) further supporting the specificity of the CD70-TTC.

The amount of ${ }^{227} \mathrm{Th}$ and ${ }^{223} \mathrm{Ra}$ (the decay product of ${ }^{227} \mathrm{Th}$ ) in the tumor and in major organs seven days after treatment are presented in Figure 4. In animals treated with CD70-TTC, the tumors had decay corrected average activity of $(9.66 \pm 3.86) \mathrm{kBq} / \mathrm{g}{ }^{227} \mathrm{Th}$ corresponding to (122 $\pm 42) \%$ of injected dose/gram (\% ID/g) in the tumor. In comparison ${ }^{227} \mathrm{Th}$-uptake in organs was less pronounced, ranging from $(19 \pm 20) \mathrm{Bq} / \mathrm{g}$ for large intestine to $(219 \pm$ 98) $\mathrm{Bq} / \mathrm{g}$ for the liver, corresponding to 0.3 and $2 \% \mathrm{ID} / \mathrm{g}$ respectively. The measured activities for ${ }^{223} \mathrm{Ra}$ ranged from below detection limits for liver and muscle to $(207 \pm 121)$
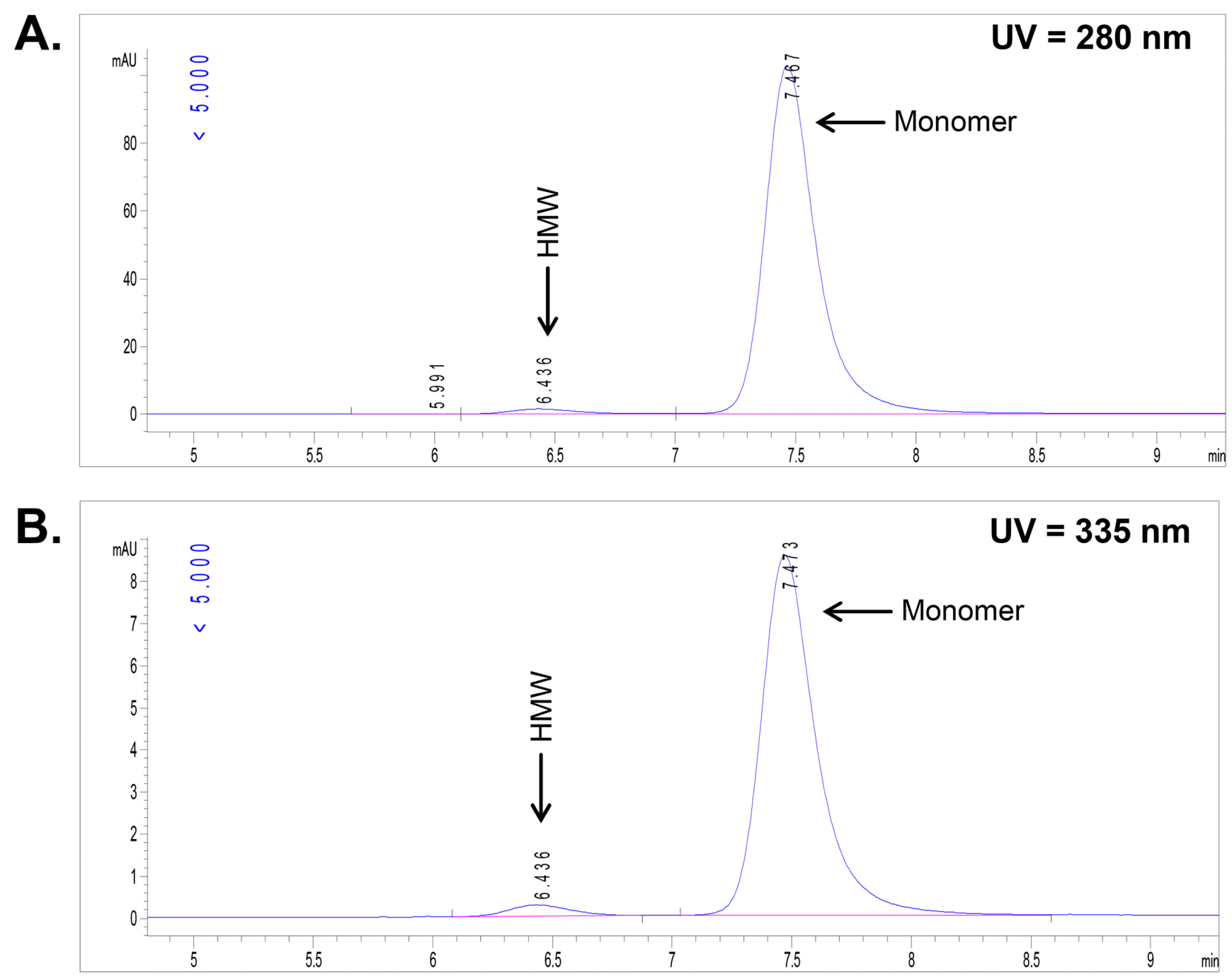

Figure 1: Determination of chelator to antibody ratio (CAR) by UV-size-exclusion chromatography. UV-absorbance for the CD70 antibody-chelator conjugate at $280 \mathrm{~nm}$ (A) and the UV-absorbance of the chelator within the CD70 antibody-chelator conjugate at $335 \mathrm{~nm}$ (B) were monitored in parallel. 
A.

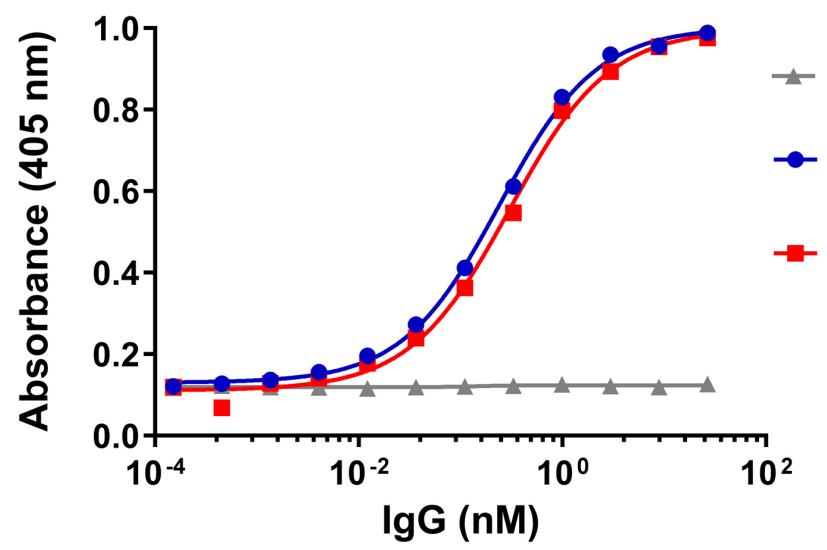

Isotype control antibody-chelator conjugate CD70 Antibody; $\mathrm{EC}_{50}=0.24 \mathrm{nM}$ CD70 Antibody-chelator conjugate; $\mathrm{EC}_{50}=0.30 \mathrm{nM}$

B.

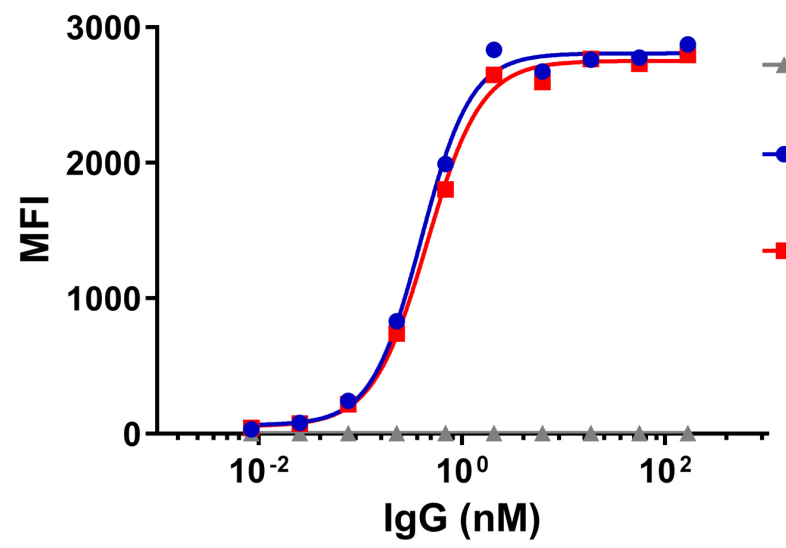

$\leftarrow$ Isotype control antibody-chelator conjugate CD70 Antibody; $\mathrm{EC} 50=0.39 \mathrm{nM}$ CD70 Antbody-chelator conjugate; $\mathrm{EC50}=0.45 \mathrm{nM}$

C.

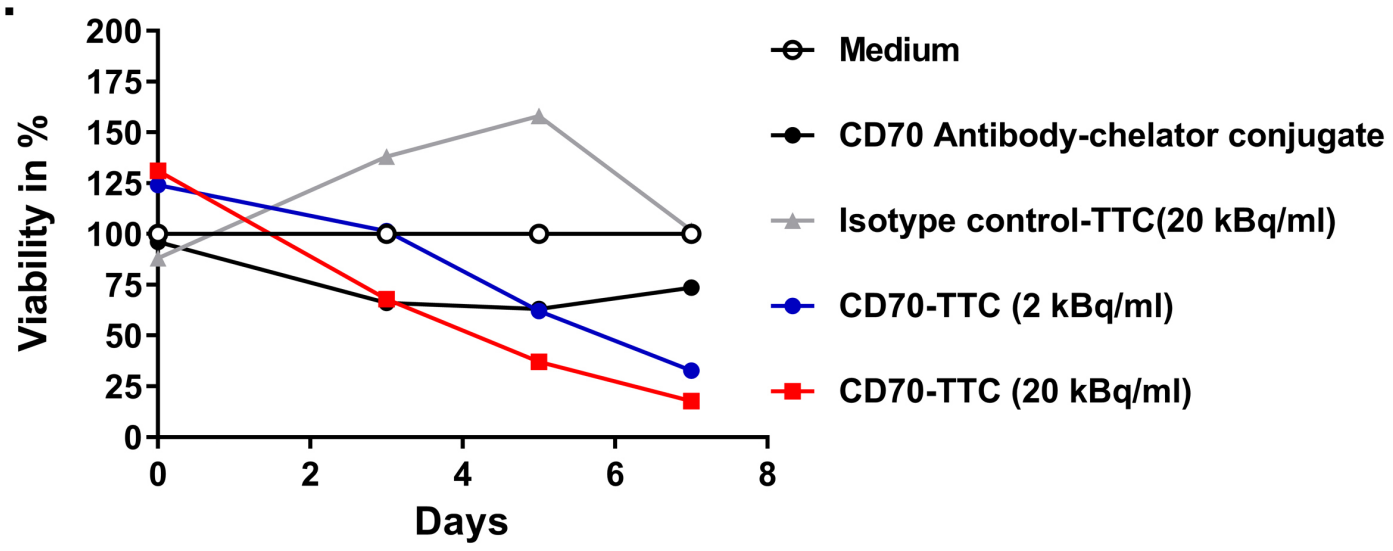

Figure 2: Comparison of binding potencies in ELISA, flow cytometry and in vitro cytotoxicity. (A) ELISA on immobilized recombinant human CD70, comparing CD70 antibody, CD70 antibody-chelator conjugate and isotype control antibody-chelator conjugate. $\mathrm{EC}_{50}$ values are given in $\mathrm{nM}$. (B) Flow cytometry analysis on human 786-O cells, comparing CD70 antibody with CD70 antibody-chelator conjugate and an isotype control antibody-chelator conjugate. $\mathrm{EC}_{50}$ values are given in $\mathrm{nM}$. (C) In vitro cytotoxicity performed using CellTiter-Glo ${ }^{\circ}$ assay for CD70-TTC and isotype control-TTC, radiolabeled at a specific activity of $50 \mathrm{kBq} / \mu \mathrm{g}$, on $786-\mathrm{O}$ cells at radioactive concentrations of 2 and $20 \mathrm{kBq} / \mathrm{ml}$. At study days 3,5 and 7, cell viability was measured and normalized to cells incubated in medium only. A non-radiolabeled CD70 antibody-chelator conjugate was included for comparison. 

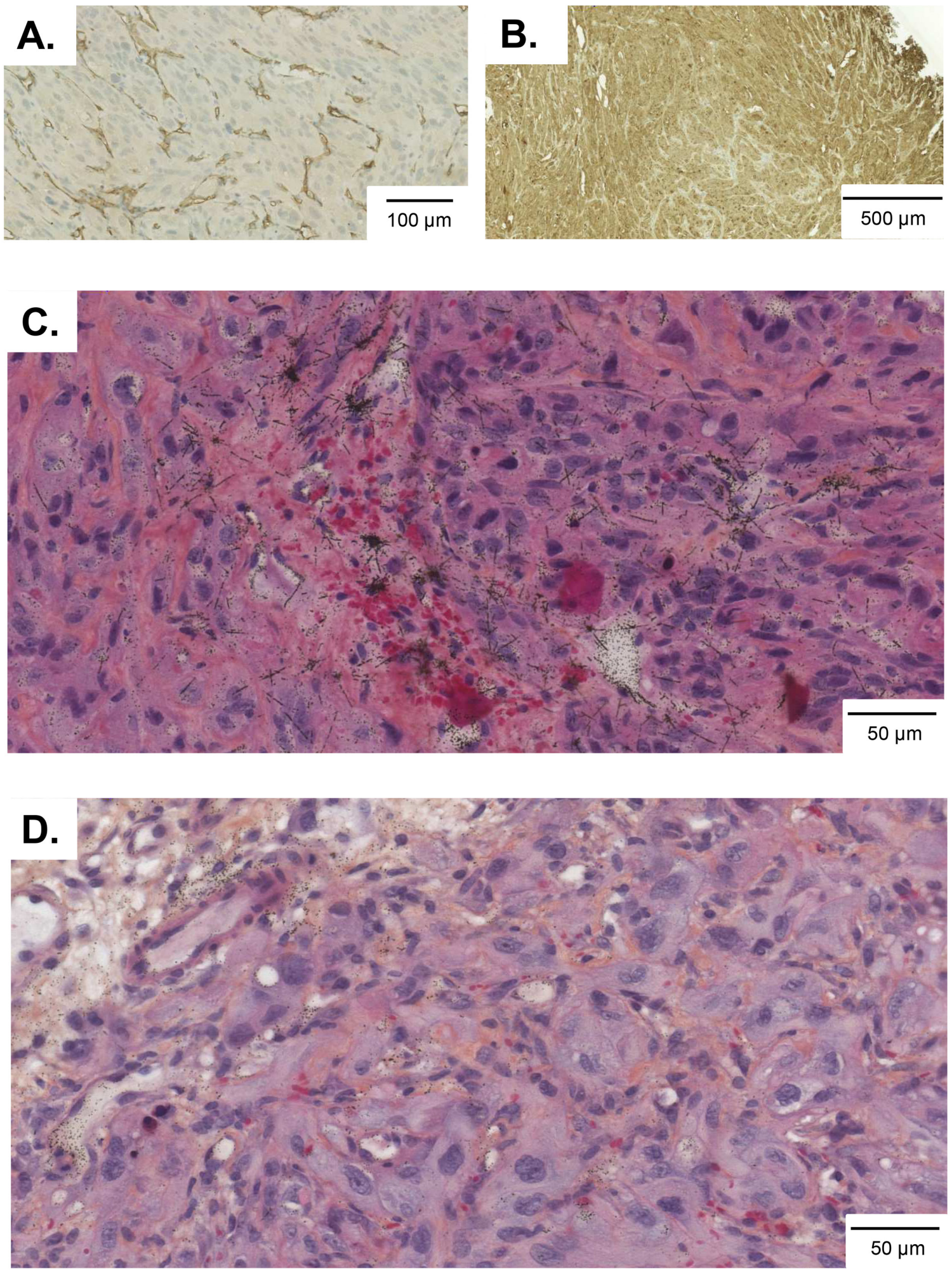

Figure 3: 786-O tumor sections from animals in the biodistribution study. Frozen tumor sections were prepared seven days after dose administration and analyzed for microvessel density (A), CD70-expression (B) and autoradiography (C) and (D). Alpha-tracks in "star-like formations" were observed in tumor sections treated with CD70-TTC (C), but not in tumors treated with isotype control-TTC (D). 


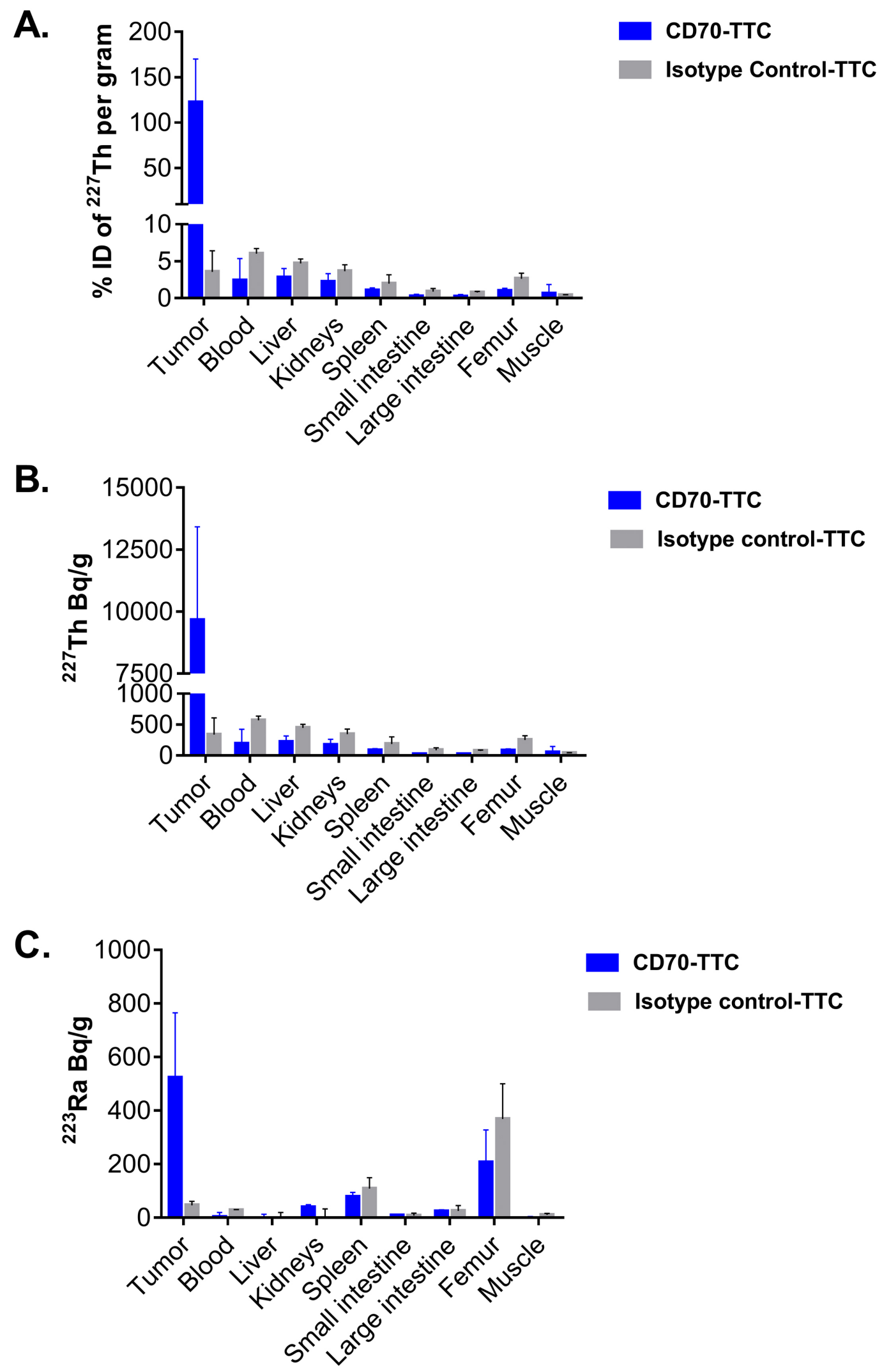

Figure 4: Biodistribution of CD70-TTC in the subcutaneous 786-O xenograft model. Biodistribution of CD70-TTC and an isotype control-TTC was analyzed 7 days after single i.v. administration of each compound at a dose of $500 \mathrm{kBq} / \mathrm{kg}$ (protein dose of $0.36 \mathrm{mg} / \mathrm{kg}$ ). (A) Accumulation of ${ }^{227} \mathrm{Th}$ expressed in $\%$ of injected dose per gram, decay corrected to the timepoint of injection in tumors and organs. (B-C) Accumulation of ${ }^{227} \mathrm{Th}(\mathrm{Bq} / \mathrm{g})$ and ${ }^{223} \mathrm{Ra}(\mathrm{Bq} / \mathrm{g})$, decay corrected to timepoint of euthanization in tumors and organs. 
$\mathrm{Bq} / \mathrm{g}$ in femur, rising to $(523 \pm 242) \mathrm{Bq} / \mathrm{g}$ in the tumors. In contrast, animals treated with the isotype control-TTC had an average activity for ${ }^{227} \mathrm{Th}$ of $(339 \pm 271) \mathrm{Bq} / \mathrm{g}$ in the tumors $(3 \% \mathrm{ID} / \mathrm{g}),(74 \pm 14) \mathrm{Bq} / \mathrm{g}$ in large intestine and $(447 \pm 57) \mathrm{Bq} / \mathrm{g}$ in liver, corresponding to 0.8 and 4.7 $\% \mathrm{ID} / \mathrm{g}$ respectively. Measured activities in muscle were $(39 \pm 4) \mathrm{Bq} / \mathrm{g}(0.6 \% \mathrm{ID} / \mathrm{g})$ and $(570 \pm 66) \mathrm{Bq} / \mathrm{g}$ in blood (5\% ID/g). For ${ }^{223} \mathrm{Ra}$, treatment with the isotype control resulted in an average concentration in tumor of (46 \pm 15$)$ $\mathrm{Bq} / \mathrm{g}$, and tissue concentrations ranged from not detected (liver and kidneys) to $(369 \pm 131) \mathrm{Bq} / \mathrm{g}$ in femur.

\section{In vivo anti-tumor activity of the CD70-TTC}

The in vivo anti-tumor activity of the CD70-TTC was assessed in the subcutaneous 786-O xenograft mouse model with lesion dimensions averaging $150 \mathrm{~mm}^{3}$. The CD70-TTC was administered as a single intravenous injection at activities of $50 \mathrm{kBq} / \mathrm{kg}, 100 \mathrm{kBq} / \mathrm{kg}, 300 \mathrm{kBq} /$ $\mathrm{kg}$ and $500 \mathrm{kBq} / \mathrm{kg}$ at a fixed protein dose of $0.36 \mathrm{mg} / \mathrm{kg}$ antibody-chelator conjugate. Additional treatment groups included the isotype control-TTC dosed at $500 \mathrm{kBq} / \mathrm{kg}$ $(0.36 \mathrm{mg} / \mathrm{kg}$ protein $)$, vehicle-treated animals and nonradiolabeled CD70 antibody-chelator conjugate $(0.36 \mathrm{mg} /$ kg protein).

At study day 103 (three out of ten animals still alive in the vehicle treated group; humane endpoint was selected to be tumor volumes $\geq 1500 \mathrm{~mm}^{3}$ ) statistical analysis of tumor growth inhibition was performed. All CD70-TTC dose groups demonstrated statistically significant tumor growth inhibition when compared to the vehicle control group (see Figure 5 and Table 1). Remarkably, based on average tumor volumes, at a dose of $100 \mathrm{kBq} / \mathrm{kg}$ tumor stasis was observed, whereas at 300 and $500 \mathrm{kBq} / \mathrm{kg}$ measurable tumor regression was achieved. In contrast, animals treated with isotype control-TTC $(500 \mathrm{kBq} / \mathrm{kg})$ showed no statistical significant decrease in tumor volume compared to vehicle demonstrating the specificity of the CD70-TTC. Analysis of the individual target lesions based on the RECIST criteria [32] (Table 1) showed that two animals treated with CD70-TTC at a dose of $50 \mathrm{kBq} / \mathrm{kg}$ had complete remissions (CR), while eight animals had progressive disease (PD). Further, at the dose of $100 \mathrm{kBq} /$ $\mathrm{kg}$, four animals had CR's whereas 6 had PD. At the dose level of $300 \mathrm{kBq} / \mathrm{kg}$, five animals had PD, one animal had stable disease (SD) and four animals showed CR's. At the top dose of $500 \mathrm{kBq} / \mathrm{kg}$, one animal had a PD, one animal a SD, 1 animal a partial response (PR) and seven animals showed CR's. In contrast, seven animals treated with isotype control-TTC $(500 \mathrm{kBq} / \mathrm{kg})$ had PD and 3 animals showed CR's.

The above described effect on tumor growth inhibition (Figure 6A) resulted in a clear dose dependent increase of median survival as illustrated in Figure 6B, and summarized in Table 1. At the end of study day 131 there were no survivors in either the vehicle or isotype control-
TTC groups, with only one animal remaining in the group treated with the non-radiolabeled CD70 antibody-chelator conjugate. In contrast, 6, 9, 8 and 10 animals survived in groups treated with $50,100,300$ or $500 \mathrm{kBq} / \mathrm{kg}$ of CD70TTC respectively. Furthermore, based on the recorded body weight gains, there were no overt signs of toxicity (Figure 6B; Table 1).

To evaluate general treatment-related toxicity in addition to body weights, blood samples from individual animals from each group were analyzed during the course of the study. Results are presented in Figure 7. Doserelated suppression of neutrophils, lymphocytes and total white blood cells (WBC) were observed for animals treated with CD70-TTC at dosages of 300 and $500 \mathrm{kBq} /$ $\mathrm{kg}$, reaching statistical significance for lymphocytes and total WBC on study day 44 compared to the vehicle control group. For the isotype control-TTC, hematological depression on day 44 was even greater, reaching statistical significance for neutrophils, lymphocytes and WBCs. On day 65 there was partial recovery in all groups, and by day 114 , complete recovery was seen in all surviving groups.

There were only minor reductions of red blood cells (RBCs), reaching statistical significance only in animals treated with isotype control-TTC $(500 \mathrm{kBq} / \mathrm{kg})$ at study day 44 and 65 compared to animals treated with vehicle (Figure 7D). No statistically significant differences in platelet counts were seen in any of the groups at any of the time points (Figure 7E).

\section{DISCUSSION}

The current treatment options for primary RCC tumors are surgery (radical or partial nephrectomy), conventional chemotherapy, as well as stereotactic radiotherapy [33]. For metastatic RCC, therapies targeted at the vascular endothelial growth factor pathway have become the standard treatment. However, drug resistance to these agents has been reported, although the exact mechanisms are currently largely still unknown [34]. Therefore, new treatment modalities, such as the recently approved multi tyrosine kinase inhibitor cabozantinib [35] and immunotherapy-based treatments targeting the PD-1/ PD-L1 axis $[36,37]$ are needed to further improve the clinical outcome in RCC.

Due to the constitutive expression of CD70 on solid tumors and B-cell lymphomas, several CD70-targeting molecules including antibodies and ADCs have recently entered preclinical and clinical testing in NHL and renal cell cancer $[24,30,38]$. In addition, the CD70-CD27 receptor-ligand pair has been suggested as a promising target for immunotherapy combinations by stimulating anti-tumor immune response, for example in NSCLC [39, 40]. In the present work, we describe the generation of a CD70-TTC that utilizes the benefits of the high linear energy transfer of alpha particle emitters delivered to the tumor by an antibody. 
A.

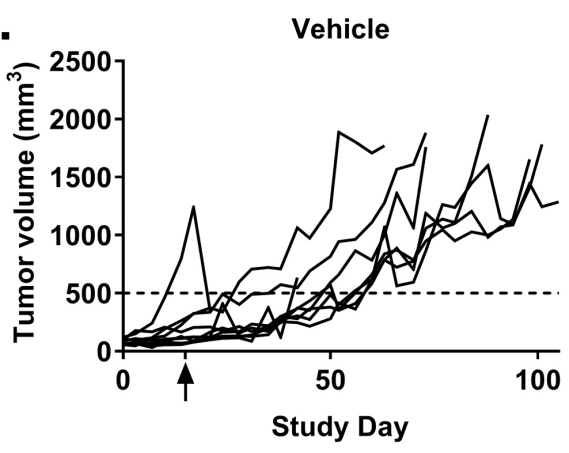

C.

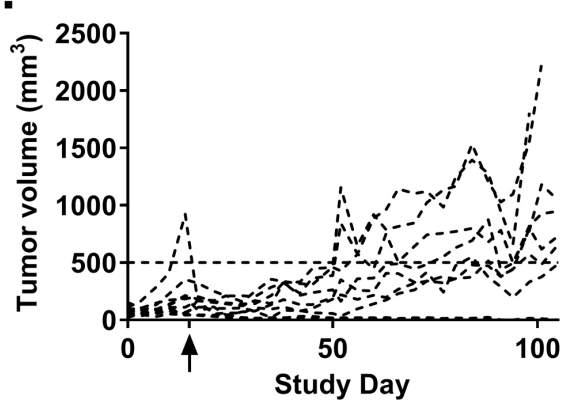

E.

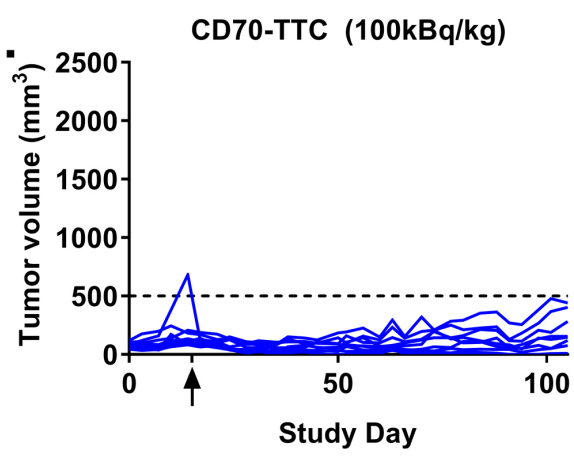

G.

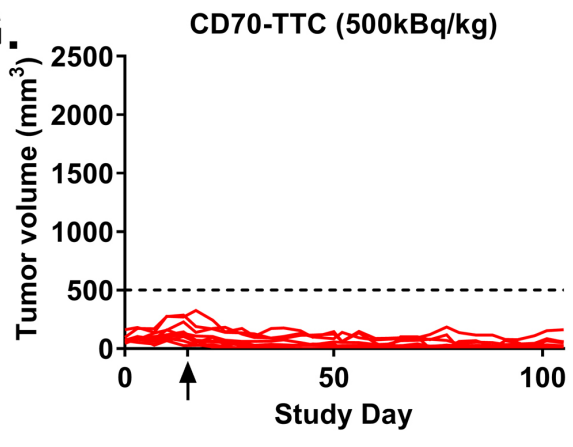

B.

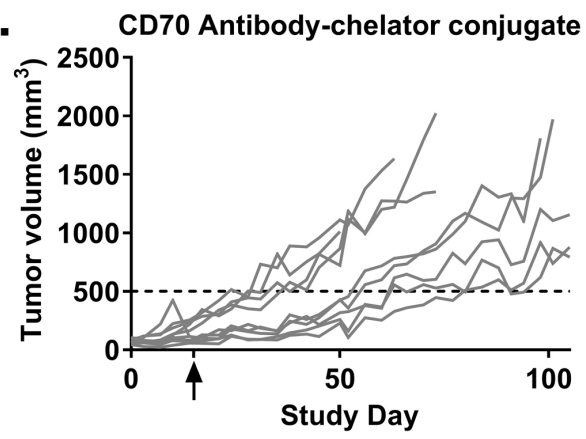

D.

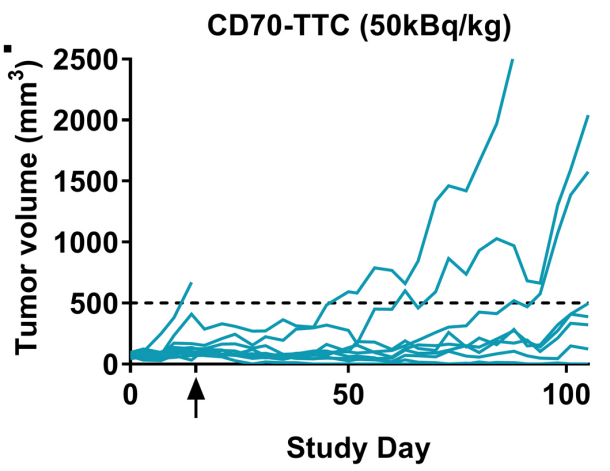

$\mathbf{F}$.

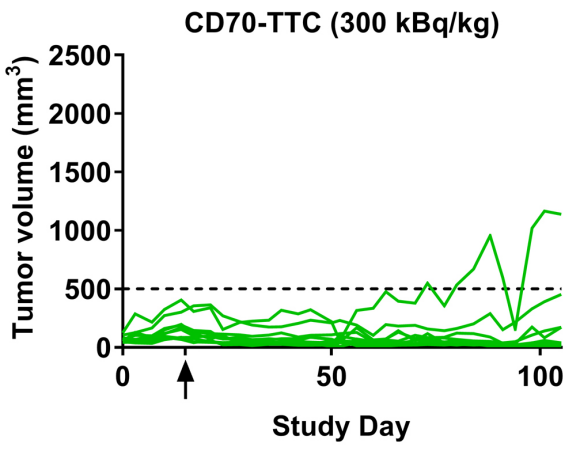

H.

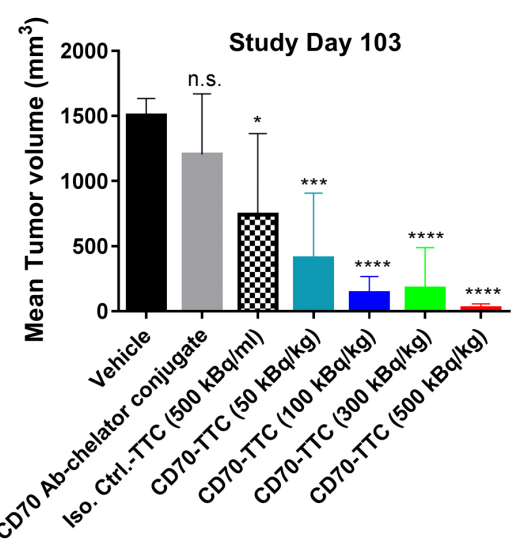

Figure 5: Individual tumor growth curves in the subcutaneous 786-O xenograft model. At an average tumor size of 150 $\mathrm{mm}^{3}$, animals received a single i.v. injection (study day 15; indicated with an arrow). (A) Vehicle. (B) CD70 antibody-chelator conjugate. (C) Isotype control-TTC $(500 \mathrm{kBq} / \mathrm{kg}$ at $0.36 \mathrm{mg} / \mathrm{kg}$ ). (D-G) CD70-TTC (doses of 50, 100, 300 and $500 \mathrm{kBq} / \mathrm{kg}$ at $0.36 \mathrm{mg} / \mathrm{kg}$ ). (H) Comparison of average tumor volumes at study day 103. Statistical analysis was performed using one-way ANOVA (Dunnett's testing) in comparison to vehicle (n.s., not significant; *, p $<0.05 ; * *, p<0.01 ; * * *, p<0.001 ; * * * *, p<0.0001$ ). 
Table 1: Tumor volumes, median survival times (MST), evaluation of target lesions and changes in body weight (BW)

\begin{tabular}{|c|c|c|c|c|c|c|c|}
\hline & \multirow{2}{*}{ Vehicle } & \multirow{2}{*}{$\begin{array}{c}\text { CD70 } \\
\text { Antibody- } \\
\text { chelator } \\
\text { conjugate }\end{array}$} & \multirow{2}{*}{$\begin{array}{c}\begin{array}{c}\text { Isotype } \\
\text { control-TTC }\end{array} \\
500 \mathrm{kBq} / \mathrm{kg}\end{array}$} & \multicolumn{4}{|c|}{ CD70-TTC } \\
\hline & & & & $50 \mathrm{kBq} / \mathrm{kg}$ & $100 \mathrm{kBq} / \mathrm{kg}$ & $300 \mathrm{kBq} / \mathrm{kg}$ & $500 \mathrm{kBq} / \mathrm{kg}$ \\
\hline $\begin{array}{l}\text { Average tumor } \\
\text { volume }\left[\mathrm{mm}^{3}\right]\end{array}$ & $\begin{array}{c}1502 \pm \\
132\end{array}$ & $1204 \pm 464$ & $953 \pm 532$ & $405 \pm 502$ & $139 \pm 128$ & $176 \pm 313$ & $24 \pm 33$ \\
\hline $\mathrm{T} / \mathrm{C}$ & $\mathrm{n} / \mathrm{a}$ & 0.8 & 0.69 & 0.27 & 0.09 & 0.12 & 0.02 \\
\hline $\begin{array}{l}\text { Statistical } \\
\text { significance }^{\mathrm{a}}\end{array}$ & $\mathrm{n} / \mathrm{a}$ & n.s. & $*$ & $* * *$ & $* * * *$ & $* * * *$ & $* * * *$ \\
\hline $\begin{array}{l}\text { MST (days; end of } \\
\text { study) }\end{array}$ & 86 & 91 & 113 & $\mathrm{n} / \mathrm{a}$ & $\mathrm{n} / \mathrm{a}$ & $\mathrm{n} / \mathrm{a}$ & $\mathrm{n} / \mathrm{a}$ \\
\hline Survival & $0 / 10$ & $1 / 10$ & $0 / 10$ & $6 / 10$ & $9 / 10$ & $8 / 10$ & $10 / 10$ \\
\hline $\begin{array}{l}\text { Statistical } \\
\text { significance }^{b}\end{array}$ & $\mathrm{n} / \mathrm{a}$ & n.s. & $*$ & $* *$ & $* * *$ & $* * * *$ & $* * * *$ \\
\hline $\begin{array}{l}\text { Target lesion } \\
\text { evaluation }\end{array}$ & $10 \mathrm{PD}$ & $9 \mathrm{PD} / 1 \mathrm{CR}$ & $7 \mathrm{PD} / 3 \mathrm{CR}$ & $8 \mathrm{PD} / 2 \mathrm{CR}$ & $6 \mathrm{PD} / 4 \mathrm{CR}$ & $\begin{array}{c}5 \mathrm{PD} / 1 \mathrm{SD} / \\
4 \mathrm{CR}\end{array}$ & $\begin{array}{l}1 \mathrm{PD} / 1 \mathrm{SD} / \\
1 \mathrm{PR} / 7 \mathrm{CR}\end{array}$ \\
\hline $\begin{array}{l}\text { BW in \% (end of } \\
\text { study) }\end{array}$ & 111 & 118 & 107 & 115 & 116 & 115 & 106 \\
\hline Survival & $0 / 10$ & $1 / 10$ & $1 / 10$ & $6 / 10$ & $9 / 10$ & $8 / 10$ & $10 / 10$ \\
\hline $\begin{array}{l}\text { Statistical } \\
\text { significance }^{\mathrm{a}}\end{array}$ & $\mathrm{n} / \mathrm{a}$ & n.s. & $* * * *$ & n.s. & n.s. & n.s. & $* * * *$ \\
\hline
\end{tabular}

Average tumor volumes and treatment over control ratio (T/C) were determined at study day 103. MST, evaluation of target lesions based on RECIST criteria and changes in BW were analyzed at the end of study.

n/a, not applicable; n.s., not significant; a, One-way ANOVA (Dunnett's test;); ${ }^{\text {, }}$ Log-Rank (Mantel-Cox) test; *, $\mathrm{p}<0.05$; **, $\mathrm{p}<0.01 ; *^{* *}, \mathrm{p}<0.001 ;{ }^{* * * *}, \mathrm{p}<0.0001 ; \mathrm{PD}$, progressive disease; $\mathrm{SD}=$ stable disease; PR, partial response; $\mathrm{CR}$, complete response.

The preparation of the CD70-TTC drug product comprises two main steps. Firstly, the chelator moiety is conjugated to the antibody, the resulting conjugate following purification and re-formulation can be radiolabeled directly with ${ }^{227} \mathrm{Th}$. All steps are performed at ambient temperature and under mild conditions with the aim of preserving protein function and avoiding formation of impurities such as complex aggregates. Indeed for the non-radioactive conjugate, aggregate levels (dimers) were found to be below $3 \%$ and both ELISA and FACS assays demonstrated high affinity binding of the antibody-chelator conjugate comparable to the parental CD70 antibody. Furthermore, on incubation with ${ }^{227} \mathrm{Th}$ for 20-30 minutes, the radiochemical purity of the resulting CD70-TTC was $\geq 95 \%$ as measured by iTLC. In addition, in in vitro cytotoxicity assays using the human derived renal cell cancer cell line 786-O, we observed a specific reduction in cell viability over time as compared to the isotype control-TTC. The specificity and mode of action $(\mathrm{MoA})$ are therefore anticipated to depend on both the targeting effect of the antibody to CD70 to the tumor cells and the emission of high energy alpha-particles inducing DNA double strand breaks (DSBs) resulting in G2 cell cycle arrest and cell death. We have previously reported data on this MoA in a recent study using a TTC targeting the CD33 receptor [8]. This has also been reported for other alpha-particle emitting nuclides such as ${ }^{213} \mathrm{Bi}$ [41] and therefore we would postulate a similar mode of action for the CD70-TTC.

In the biodistribution study performed in tumor bearing animals using the human renal cancer cell line 786-O, high levels of tumor uptake were measured with $(122 \pm 42) \%$ of the injected dose per gram of the CD70TTC retained in the tumor compared to only $\sim 3 \%$ ID per gram for the isotype control-TTC, a 40 fold difference at day 7. In contrast, the measured accumulation of ${ }^{227} \mathrm{Th}$ in normal tissues and blood were at lower levels in the CD70-TTC treated animals compared to the isotype control-TTC animals, most likely due to the greater target-mediated accumulation of the CD70-TTC in the tumor leading to more rapid blood clearance of CD70TTC and reduced uptake into normal tissue. The high accumulation of ${ }^{227} \mathrm{Th}$ in the tumor is driven by (a) the binding properties of the non-mouse cross-reactive CD70 antibody-chelator conjugate combined with (b) the high levels of CD70 target expression in this model (c) low 
A.

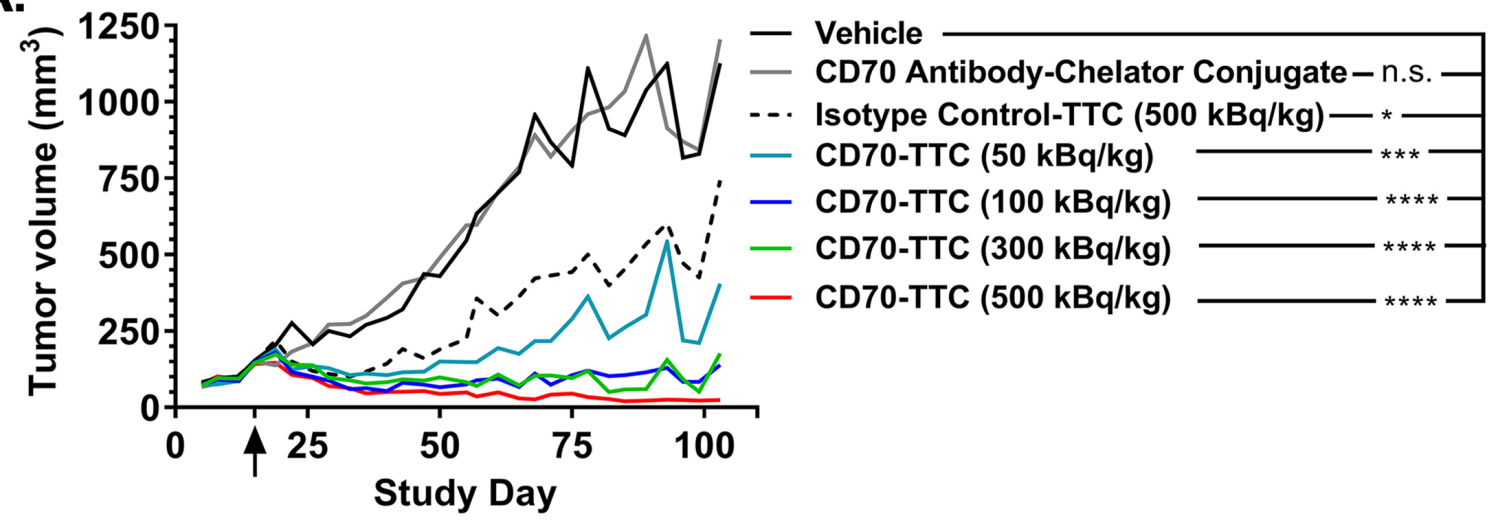

B.
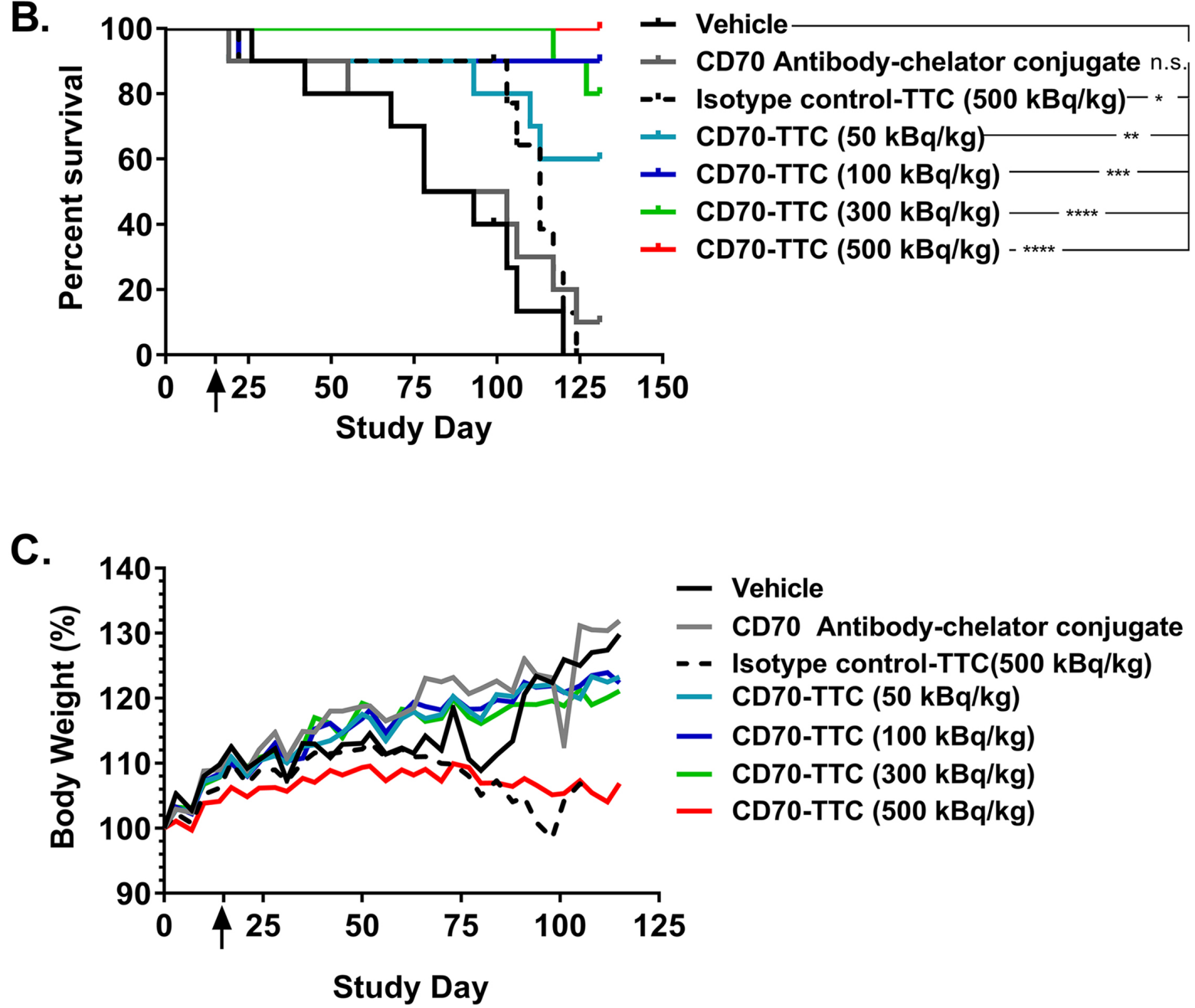

Figure 6: Average tumor growth inhibition, survival analysis and body weight changes. Start of treatment is indicated with an arrow in each plot (study day 15). (A) Average tumor growth inhibition until study day 103. Statistical analysis was performed using one-way ANOVA (Dunnett's testing) in comparison to vehicle (n.s., not significant; *, p $<0.05$; **, p $<0.01 ; * * *, p<0.001 ; * * * *, p<$ 0.0001. (B) Survival plot analysis of animals sacrificed due to humane endpoint (tumor volume $>1500 \mathrm{~mm}^{3}$ ). Animals were either treated with vehicle, CD70 antibody-chelator conjugate, isotype control-TTC $(500 \mathrm{kBq} / \mathrm{kg} ; 0.36 \mathrm{mg} / \mathrm{kg})$ or with CD70-TTC at the indicated doses $(50,100,300$ or $500 \mathrm{kBq} / \mathrm{kg} ; 0.36 \mathrm{mg} / \mathrm{kg})$. The median survival time (MST) for the vehicle control group was determined to be 86 days and the MST of the CD70 antibody-chelator conjugate was 91 days, whereas the MST for animals treated with isotype control-TTC was 113 days. The MST for groups receiving CD70-TTC could not be determined. Data were analyzed using Log-Rank (Mantel-Cox) analysis (n.s., not significant; *, p < 0.05, **, p < 0.01; ***, p < 0.001; ****, p $<0.0001$ ). (C) Changes in body weight, expressed in \% 

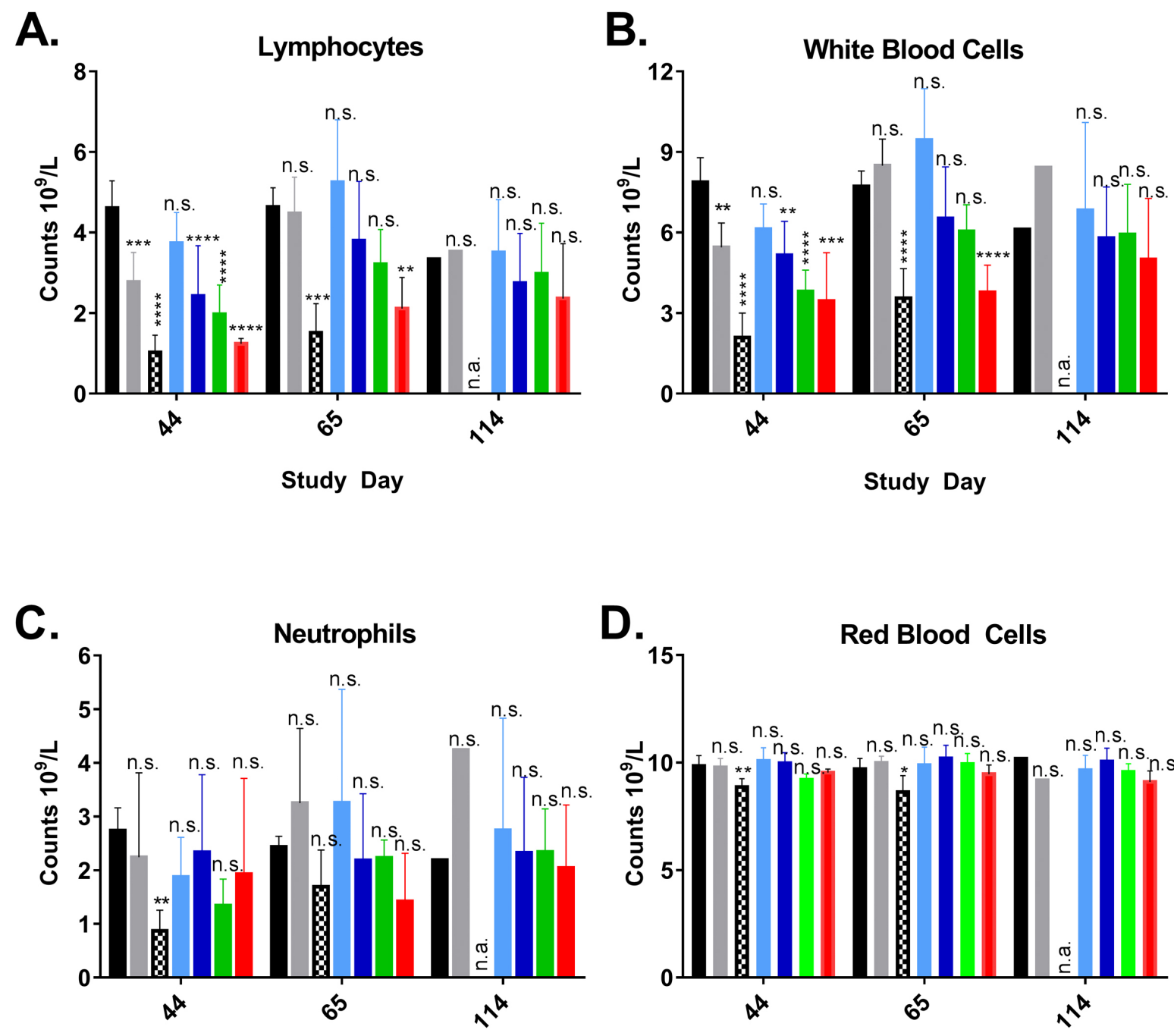

Study Day

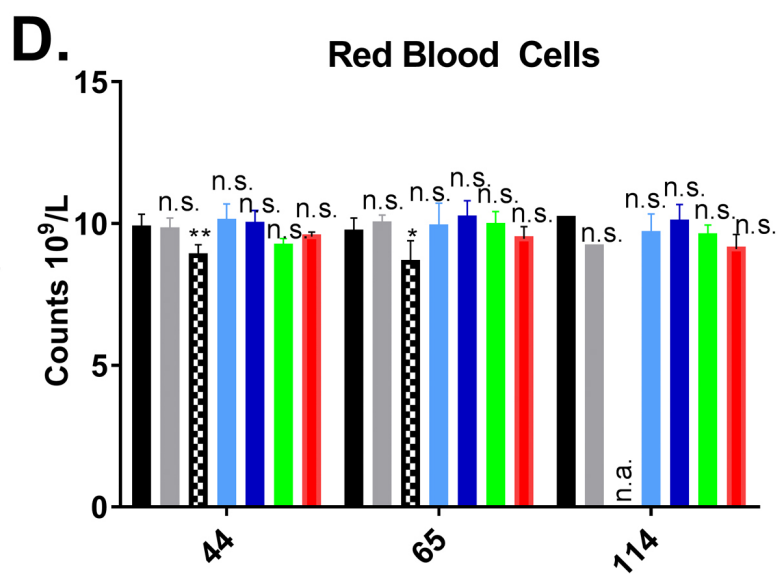

Study Day
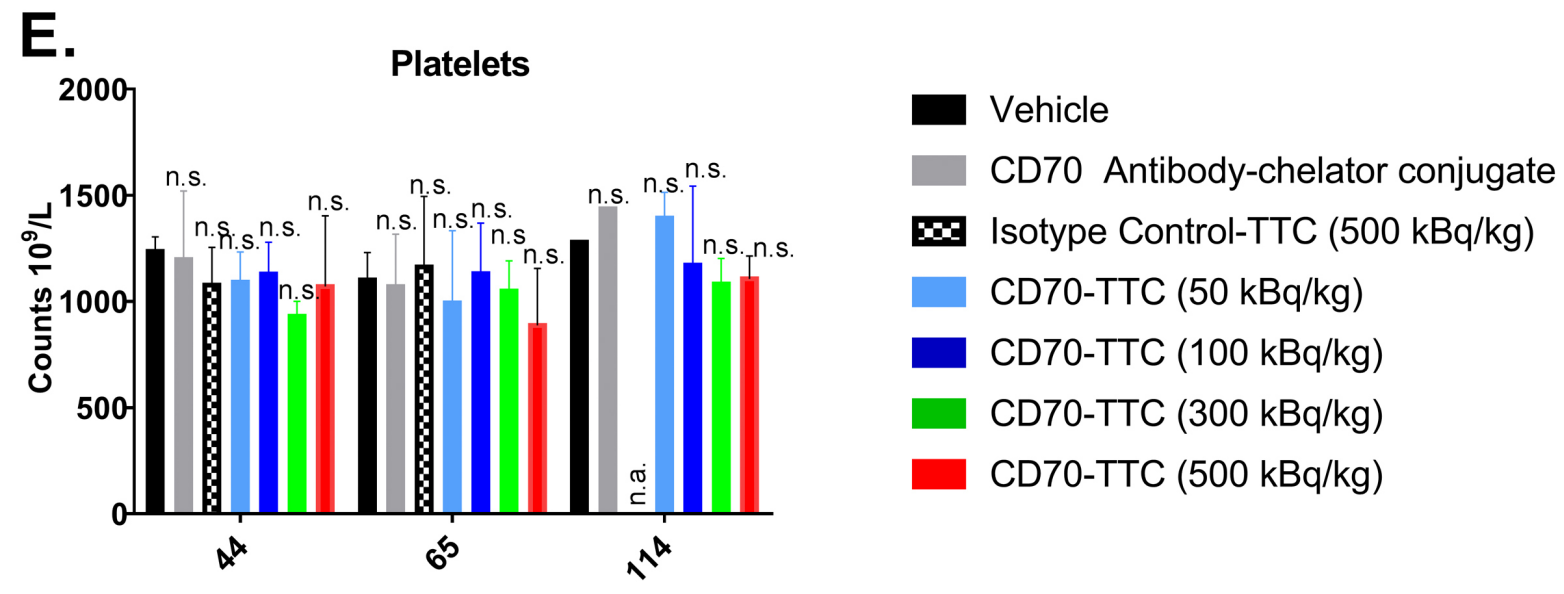

Isotype Control-TTC (500 kBq/kg)

CD70-TTC $(50 \mathrm{kBq} / \mathrm{kg})$

- CD70-TTC $(100 \mathrm{kBq} / \mathrm{kg})$

CD70-TTC $(300 \mathrm{kBq} / \mathrm{kg})$

CD70-TTC $(500 \mathrm{kBq} / \mathrm{kg})$

Study Day

Figure 7: Hematology during course of in vivo efficacy study. Blood chemistry analysis was performed at study day 44, 65 and 114. Statistical analysis was performed using one-way ANOVA (Dunnett's testing) using vehicle as baseline (n.s., not significant; *, $\mathrm{p}<$ $0.05, * *, p<0.01 ; * *, p<0.001 ; * * * *, p<0.0001)$. At day 114 , no animals treated with isotype control-TTC were alive and therefore blood analysis was not applicable (n.a.). (A) White blood cell counts. (B) Lymphocytes. (C) Neutrophils. (D) Red blood cell. (E) Platelets. 
levels of necrosis (ranging from not detectable to $14 \%$ ) and (d) high vascularity of the tumors (MVD $~ 324 / \mathrm{mm}^{2}$ ).

${ }^{223} \mathrm{Ra}$ concentrations in all tissues were less than for ${ }^{227} \mathrm{Th}$ with the exception of femur where slow accumulation of ${ }^{223} \mathrm{Ra}$ activity was observed reflecting the release from the chelator and redistribution of ${ }^{223} \mathrm{Ra}$, a bone seeking radionuclide [4]. To better understand the pharmacokinetic properties of the CD70-TTC, accumulation of ${ }^{227} \mathrm{Th}$ and ${ }^{223} \mathrm{Ra}$ in the different organs at additional timepoints (early and later than day 7) will be needed.

Statistically significant in vivo potency was achieved at all doses tested with complete tumor growth inhibition observed at doses as low as $50 \mathrm{kBq} / \mathrm{kg}$. Although doses of $500 \mathrm{kBq} / \mathrm{kg}$ of the isotype control-TTC reached some statistical significance when examining the average tumor volume, this can be explained by the enhanced permeability and retention (EPR) effect, a common feature of antibodies [42, 43]. The efficacy in this model also translated to an increase in median survival times of the treatment group compared to control animals.

Myelosuppression was observed as a dose-related depression of circulating neutrophils, lymphocytes and total white blood cells over the course of 114 days as compared to the vehicle-treated animals. However, this toxicity appeared to be reversible with partial recovery of neutrophils, lymphocytes and white blood cells evident at 65 days and complete recovery by day 114 post dosing. The reversible hematological depression is in agreement with the previously reported literature for ${ }^{227} \mathrm{Th}$-based radioimmunoconjugates $[8,44]$. The higher depression of neutrophils, lymphocytes and total WBCs seemed to be more pronounced for the isotype control-TTC and might be explained by the difference in pharmacokinetic profile with the higher levels of ${ }^{227} \mathrm{Th}$ circulating in blood resulting in greater exposure of the systemic lymphoid tissues and bone marrow. No impact on red blood cells or platelets was observed. Although these toxicological findings in mice are encouraging, further toxicological experiments in non-rodent species will be needed to further evaluate myelosuppression as it is well accepted that rodents show greater resistance to radiation, including external beam radiation. As such the LD50 dose for rodents has been described to be in the range of 500 to $1000 \mathrm{rad}$ (depending on the age of the animals) [45] in comparison to an LD50 of 500 rad in humans [46]. As expected from previous studies, no major findings were recorded in renal toxicity caused by accumulation of the daughter nuclides of ${ }^{227} \mathrm{Th}$ [44] in contrast to redistribution of ${ }^{213} \mathrm{Bi}$ formed from decay of ${ }^{225} \mathrm{Ac}$-based radioimmunoconjugates [47].

In summary, the in vitro and in vivo preclinical data provided herein for CD70 expressing tumor cells of renal cell carcinoma origin supports the further development of a CD70-TTC for this indication. As recently presented the optimized chelator chemistry allows both conjugation and radiolabeling steps to be performed under mild conditions and is applicable to a wide variety of targeting moieties $[6,8]$.

\section{MATERIALS AND METHODS}

\section{Cells}

The human renal cell cancer cell line 786-O was obtained from ATCC (Manassas, VA, USA) and was authenticated using PCR fingerprinting by the provider. The cell line was maintained in an incubator with an atmosphere containing $5 \% \mathrm{CO}_{2}$ at $37^{\circ} \mathrm{C}$ using RPMI-1640 medium supplemented with $10 \%(\mathrm{w} / \mathrm{v})$ fetal calf serum (FCS) and $1 \%(\mathrm{v} / \mathrm{v})$ penicillin and streptomycin.

\section{Synthesis of the chelator}

The 3,2-HOPO chelator was synthesized in 4 steps from the starting materials N1,N1'-(2-(4-nitrobenzyl) propane-1,3-diyl)bis(N1-(2-aminoethyl)ethane-1,2diamine) and 3-(benzyloxy)-1-(2-(benzyloxy)ethyl)-4(2-thioxothiazolidine-3-carbonyl)pyridin-2(1H)-one [6].

\section{Preparation and characterization of CD70 antibody-chelator conjugate}

Conjugation of the 3,2-HOPO chelator ( $494 \mu \mathrm{g}$ ) to a (non-cross-reactive to mouse) anti-human CD70 antibody (IgG1; $40 \mathrm{mg}$ ) was achieved through NHS-coupling of the 3,2-HOPO chelator to the lysine residues present in the antibody at a molar ratio of 3:1, respectively, and incubation for $1 \mathrm{~h}$ at $21^{\circ} \mathrm{C}$ in PBS, $\mathrm{pH}$ 7.0. Monomeric fractions of the resulting CD70 antibody-chelator conjugate were separated from high-molecular weight (HMW) fractions using a HiLoad 16/600 Superdex 200 prep-grade SEC column (GE Healthcare) in formulation buffer. An isotype antibody-chelator conjugate was prepared in parallel.

The chelator to antibody ratio (CAR) was determined using a SEC-UV based method. Antibodychelator conjugates were injected on a TSKgel SUPER SW 3000 column (Tosoh) using PBS/ $0.3 \mathrm{M} \mathrm{NaClO}_{4}$ as the mobile phase, and the absorbance of the antibody-chelator conjugates at $280 \mathrm{~nm}$ and $335 \mathrm{~nm}$ (corresponding to the absorbance of the chelator) within the monomeric fraction was recorded. The CAR value was calculated using the following formula:

$$
\mathrm{CAR}=\frac{\left(\varepsilon m A b 335-\left(R^{*} \varepsilon m A b 280\right)\right.}{\left(\left(R^{*} \varepsilon c 280\right)-\varepsilon c 335\right)},
$$

with $\varepsilon m A b$ being the extinction coefficient of the antibody at 335 and $280 \mathrm{~nm}, \varepsilon \mathrm{c}$ being the extinction coefficient of the chelator at 335 and $280 \mathrm{~nm}$ and $\mathrm{R}$ being the chelator to $\mathrm{mAb}$ area ratio determined from the chromatograms. The CAR was determined to be 1.0 . 


\section{Radiolabeling of CD70-TTC}

${ }^{227} \mathrm{Th}$ was harvested from an ${ }^{227} \mathrm{Ac}$ generator and the resulting purified isotope was stored in a solution of $0.05 \mathrm{M}$ hydrochloric acid, containing metal-free water. Before radiolabeling, ${ }^{227} \mathrm{Th}$ was further purified from the daughter ${ }^{223} \mathrm{Ra}$ (including its short-lived progenies) using a strong anion exchange material as described in [48]. Two-hundred and fifty micrograms of antibodychelator conjugate in formulation buffer were mixed with added ${ }^{227} \mathrm{Th}$ activities in the range of $0.2-2.5 \mathrm{MBq}$, and incubated at room temperature for $20-30$ minutes. Radiochemical purities (RCP) were determined by instant Thin-Layer Chromatography (iTLC) and were consistently in the range of $\geq 95 \%$.

\section{Binding to CD70 antigen by ELISA and FACS analysis}

To compare the binding properties of the CD70 antibody with the CD70 antibody-chelator conjugate, binding experiments to recombinant human CD70 in ELISA were performed. A 96 well plate (NUNC; Maxisorp) was coated with $3.5 \mu \mathrm{g} / \mathrm{ml}$ of anti-FLAG M2 antibody (Sigma Aldrich) diluted in PBS and incubated overnight at $4^{\circ} \mathrm{C}$. The next day, the plate was washed 3 times with $250 \mu \mathrm{l} /$ well wash buffer (PBS with $0.1 \%$ (v/v) tween) using a plate washer. ELISA wells were blocked with $250 \mu \mathrm{l} /$ well of $4 \%$ PBS-milk for $2 \mathrm{~h}$. The plate was washed 3 times with $250 \mu \mathrm{l} /$ well wash buffer using a plate washer afterwards and recombinant FLAG-TNC-CD70 was added at a concentration of $0.1 \mu \mathrm{g} / \mathrm{ml}$ in PBS-milk $0.1 \%(\mathrm{w} / \mathrm{v})$ to each well. The plate was incubated for $1 \mathrm{~h}$ at room temperature and washed as outlined above. Serial dilutions (1:3) of CD70 antibody and CD70 antibodychelator conjugate at starting concentrations of $4 \mu \mathrm{g} / \mathrm{ml}$ were added to the wells and incubated for an additional hour to allow binding to the target. Bound samples were detected by addition of $100 \mu \mathrm{l} /$ well of anti-human-IgGHRP antibody (Southern Biotech) diluted 1:15 000 in PBS with $0.4 \%(\mathrm{w} / \mathrm{v})$ milk. The plate was incubated for 30 minutes (min), washed, then $100 \mu \mathrm{l}$ of ABTS (Thermo Scientific Pierce) was added to all wells. The plate was incubated for 5-10 minutes at room temperature and analyzed by measuring the absorbance at $450 \mathrm{~nm}$ in a plate reader (Perkin Elmer). The $\mathrm{EC}_{50}$ values were calculated using GraphPad Software.

Binding properties were tested on CD70-positive human 786-O cells. Cells were harvested from culture using trypsin, spun down at $300 \mathrm{~g}$ for 5 minutes at $4^{\circ} \mathrm{C}$ and washed with flow buffer (PBS with $0.5 \%(\mathrm{w} / \mathrm{v})$ fetal calf serum (FCS)). Cells were pelleted again by centrifugation ( $300 \mathrm{~g})$, suspended in flow buffer and 50000 cells/well transferred to a V-shaped 96 well plate. After centrifugation ( $5 \mathrm{~min}$ at $300 \mathrm{~g}$ at $4^{\circ} \mathrm{C}$ ), serial dilutions (1:3) of CD70 antibody and CD70 antibody-chelator conjugate were added to the cells at a starting concentration of 50 $\mu \mathrm{g} / \mathrm{ml}$. Samples were incubated for $1 \mathrm{~h}$ at $4^{\circ} \mathrm{C}$. Unbound samples were washed off by excess flow buffer with an intermediate centrifugation step ( $5 \mathrm{~min}$ at $300 \mathrm{~g}$ at $4^{\circ} \mathrm{C}$ ). Remaining bound samples were incubated with a 1:50 dilution of anti-mouse IgG-PE (Biolegend) antibody for 1 $\mathrm{h}$ at $4^{\circ} \mathrm{C}$ in the dark. The cells were washed twice with icechilled flow buffer with an intermediate centrifugation step and the mean fluorescence intensity (MFI) was recorded using a Quanta SC MPL machine (Beckman Coulter). The $\mathrm{EC}_{50}$ values were calculated based on the recorded median fluorescence intensities (MFI), using GraphPad software, also used for additional evaluations.

\section{In vitro cytotoxicity of CD70-TTC}

The 786-O cells were harvested from culture flasks, counted and seeded at a density of 100.000 cells $/ \mathrm{ml}$ into 24-well culture plates. Cells were incubated for $3 \mathrm{~h}$ at $37^{\circ} \mathrm{C}$ with activities of 2 and $20 \mathrm{kBq} / \mathrm{ml}$ of CD70-TTC or an untargeted isotype control-TTC, both radiolabeled at a specific activity of $50 \mathrm{kBq} / \mu \mathrm{g}$. A non-radiolabeled CD70 antibody-chelator conjugate sample was incubated on cells in parallel. Cells were washed with fresh medium after treatment and seeded into a new 24-well culture plate. At days 3, 5 and 7, cells were harvested and the viability was measured using the CellTiterGlo kit (Promega). The viability of treated cells was expressed as \% of control cells that had been cultured in medium only.

\section{Animal models}

Animal studies were conducted in collaboration with Pharmatest Services Ltd (Turku, Finland) with maintenance of rodents under barrier and pathogenfree conditions. Ethical approval was received from the National Committee for Animal Experiments (license number ESAVI-6057-04.10.03-2011). In all studies, animals received an intraperitoneal (i.p.) injection of an unrelated murine IgG2a antibody ( $200 \mu \mathrm{g} / \mathrm{animal}$; UPC10; Sigma) 24 hours prior treatment to block unspecific spleen uptake [49]. Experiments were conducted using female NMRI nu/nu mice (Charles River, Germany) with a median weight of 18 to 25 gram and an average age of 7 to 10 weeks. Animals were injected with 5 x 106 786-O cells, suspended in $0.1 \mathrm{ml}$ of $50 \%$ matrigel (BD Biosciences). Subcutaneous tumor growth was monitored by measuring the tumor volume twice a week using a caliper and using the formula: $\mathrm{V}=0.5 \times(\text { length }+ \text { width })^{2}$. During efficacy studies animals were sacrificed by cervical dislocation upon reaching the humane endpoint with a tumor volume of $1.5 \mathrm{~cm}^{3}$ or a body weight loss $\geq 20 \%$.

For biodistribution, tumors were grown until an average volume of $200-300 \mathrm{~mm}^{3}$ was reached. On the day of treatment, animals received a single intravenous injection of the CD70-TTC or an isotype control-TTC, 
both at a radioactive dose of $500 \mathrm{kBq} / \mathrm{kg}$ and a fixed protein dose of $0.36 \mathrm{mg} / \mathrm{kg}$. Tumors and organs were harvested 7 days after dose administration and the radioactivity was counted using a high-purity germanium detector (HPGe) linked to an autosampler (Gamma Data). To identify ${ }^{227} \mathrm{Th}$ and ${ }^{223} \mathrm{Ra}$, the GammaVision software and Npp32 analysis engine (Reg. Guide 4.16 detection limit method) were used. For ${ }^{227}$ Th measurement, the $235.96 \mathrm{keV}$ (abundance $12.90 \%$ ), $256.23 \mathrm{keV}$ (abundance 7.00\%), $329.85 \mathrm{keV}$ (2.90\% abundance), $286.09 \mathrm{keV}$ (abundance 1.74\%), $304.50 \mathrm{keV}$ (abundance 1.15\%), $334.37 \mathrm{keV}$ (abundance $1.14 \%$ ), and $299.98 \mathrm{keV}$ (abundance $2.21 \%$ ) gamma peaks were used. About $323.87 \mathrm{keV}$ (abundance 3.99\%), 338.28 $\mathrm{keV}$ (abundance 2.84\%), $445.03 \mathrm{keV}$ (abundance 1.29\%), $269.46 \mathrm{keV}$ (abundance 13.90\%), $154.21 \mathrm{keV}$ (abundance $5.70 \%$ ), and $144.24 \mathrm{keV}$ (abundance $3.27 \%$ ) gamma peaks were used for ${ }^{223} \mathrm{Ra}$ measurement. Thorium-227 counts were corrected to the time of injection and expressed as $\%$ of injected dose of ${ }^{227} \mathrm{Th}$. Further, ${ }^{227} \mathrm{Th}$ and ${ }^{223} \mathrm{Ra}$ counts were corrected to time of euthanization and expressed in $\mathrm{Bq} / \mathrm{g}$.

For efficacy studies, treatment was initiated at an average tumor volume of approximately $150 \mathrm{~mm}^{3}$. On the day of treatment, animals received a single intravenous injection of CD70-TTC, unlabeled CD70 antibodychelator conjugate or vehicle (formulation buffer). CD70TTC was dosed at radioactive doses of 50, 100, 300 and $500 \mathrm{kBq} / \mathrm{kg}$ at a fixed protein dose of $0.36 \mathrm{mg} / \mathrm{kg}$. A separate group of animals was treated with an untargeted isotype control-TTC at a radioactive dose of $500 \mathrm{kBq} /$ $\mathrm{kg}$ at a fixed protein dose of $0.36 \mathrm{mg} / \mathrm{kg}$. Tumor growth was monitored by measuring the tumor volumes twice a week along with the body weights. Blood samples $(200 \mu \mathrm{l})$ for hematology were taken from the saphenous vein into capillary tubes containing EDTA after heating the animals under a halogen lamp. The samples were mixed and the blood was analyzed (Siemens ADVIA 120).

Statistical analysis was performed using GraphPad software, applying one-way ANOVA (Dunnett's testing; tumor growth inhibition and body weights) and log-rank (Mantel-Cox) tests (survival analysis).

\section{Immunohistochemistry and autoradiography}

Tumors from mice allocated to the biodistribution part of the study and treated with the CD70-TTC or the isotype control-TTC were harvested on day 7 and analyzed for target expression (CD70), microvessel density (CD34) and necrosis. Tumors were embedded in paraffin blocks, sectioned at $4 \mu \mathrm{m}$ and stained with either anti-mouse CD34 (MEC 14.7, sc-18917, Santa Cruz Biotechnology Inc; $4 \mu \mathrm{g} / \mu \mathrm{l}$ ) or with anti-human-CD70 antibody (clone \#301731; R\&D Systems; $25 \mu \mathrm{g} / \mathrm{ml}$ ). For autoradiography, the sections were dewaxed then dipped in Ilford K5 emulsion (Polysciences Inc.), held in a light-proof box at room temperature for up to 3 days and processed according to the manufacturer's instructions. All sections were counterstained with Harris' hematoxylin containing $0.6 \%$ Eosin Y with $1 \%$ Phloxine B and $2 \%$ Orange G. For autoradiographic and histological assessment, stained slides were scanned with a Panoramic 250 Digital Slide Scanner (3DHistec Ltd, Hungary). All histological and autoradiographic procedures were conducted at the research facilities of Pharmatest Services Ltd (Turku, Finland).

\section{ACKNOWLEDGMENTS}

We thank Pharmatest Services Ltd (Finland) for their expertise in conducting the animal experiments and immunohistochemistry analysis.

\section{CONFLICTS OF INTEREST}

The authors declare no conflicts of interest. All authors are employees by Bayer AS.

\section{REFERENCES}

1. Allen BJ, Huang CY, Clarke RA. Targeted alpha anticancer therapies: update and future prospects. Biologics. 2014; 8: 255-67. doi: 10.2147/BTT.S29947.

2. Supiot S, Faivre-Chauvet A, Couturier O, Heymann MF, Robillard N, Kraeber-Bodere F, Morandeau L, Mahe MA, Cherel M. Comparison of the biologic effects of MA5 and B-B4 monoclonal antibody labeled with iodine-131 and bismuth-213 on multiple myeloma. Cancer. 2002; 94 : 1202-9.

3. Parker C, Nilsson S, Heinrich D, Helle SI, O'Sullivan JM, Fossa SD, Chodacki A, Wiechno P, Logue J, Seke M, Widmark A, Johannessen DC, Hoskin P, et al. Alpha emitter radium-223 and survival in metastatic prostate cancer. N Engl J Med. 2013; 369: 213-23. doi: 10.1056/ NEJMoa1213755.

4. Abou DS, Ulmert D, Doucet M, Hobbs RF, Riddle RC, Thorek DL. Whole-body and microenvironmental localization of radium-223 in naive and mouse models of prostate cancer metastasis. J Natl Cancer Inst. 2016; 108. doi: 10.1093/jnci/djv380.

5. Henriksen G, Hoff P, Larsen RH. Evaluation of potential chelating agents for radium. Appl Radiat Isot. 2002; 56: 667-71.

6. Ramdahl T, Bonge-Hansen HT, Ryan OB, Larsen S, Herstad G, Sandberg M, Bjerke RM, Grant D, Brevik EM, Cuthbertson AS. An efficient chelator for complexation of thorium-227. Bioorg Med Chem Lett. 2016; 26: 4318-21. doi: 10.1016/j.bmcl.2016.07.034.

7. Kim YS, Brechbiel MW. An overview of targeted alpha therapy. Tumor Biol. 2012; 33: 573-90.

8. Hagemann UB, Wickstroem K, Wang E, Shea AO, Sponheim K, Karlsson J, Bjerke RM, Ryan OB, Cuthbertson AS. In vitro and in vivo efficacy of a novel 
CD33 targeted thorium-227 conjugate for the treatment of acute myeloid leukemia. Mol Cancer Ther. 2016; 15: 242231. doi: 10.1158/1535-7163.MCT-16-0251.

9. Bodmer JL, Schneider P, Tschopp J. The molecular architecture of the TNF superfamily. Trends Biochem Sci. 2002; 27: 19-26.

10. Coquet JM, Ribot JC, Babala N, Middendorp S, van der Horst G, Xiao Y, Neves JF, Fonseca-Pereira D, Jacobs H, Pennington DJ, Silva-Santos B, Borst J. Epithelial and dendritic cells in the thymic medulla promote CD4+Foxp3+ regulatory $\mathrm{T}$ cell development via the CD27-CD70 pathway. J Exp Med. 2013; 210: 715-28. doi: 10.1084/jem.20112061.

11. Hishima T, Fukayama M, Hayashi Y, Fujii T, Ooba T, Funata N, Koike M. CD70 expression in thymic carcinoma. Am J Surg Pathol. 2000; 24: 742-6.

12. Kashii Y, Giorda R, Herberman RB, Whiteside TL, Vujanovic NL. Constitutive expression and role of the TNF family ligands in apoptotic killing of tumor cells by human NK cells. J Immunol. 1999; 163: 5358-66.

13. Nolte MA, van Olffen RW, van Gisbergen KP, van Lier RA. Timing and tuning of CD27-CD70 interactions: the impact of signal strength in setting the balance between adaptive responses and immunopathology. Immunol Rev. 2009; 229: 216-31. doi: 10.1111/j.1600-065X.2009.00774.x.

14. Orengo AM, Cantoni C, Neglia F, Biassoni R, Ferrini S. Reciprocal expression of CD70 and of its receptor, CD27, in human long term-activated $\mathrm{T}$ and natural killer (NK) cells: inverse regulation by cytokines and role in induction of cytotoxicity. Clin Exp Immunol. 1997; 107: 608-13.

15. Wajant H. Therapeutic targeting of CD70 and CD27. Expert Opin Ther Targets. 2016; 20: 959-73. doi: 10.1517/14728222.2016.1158812.

16. Lens SM, Drillenburg P, den Drijver BF, van Schijndel G, Pals ST, van Lier RA, van Oers MH. Aberrant expression and reverse signalling of CD70 on malignant B cells. Br J Haematol. 1999; 106: 491-503.

17. Agathanggelou A, Niedobitek G, Chen R, Nicholls J, Yin W, Young LS. Expression of immune regulatory molecules in Epstein-Barr virus-associated nasopharyngeal carcinomas with prominent lymphoid stroma. Evidence for a functional interaction between epithelial tumor cells and infiltrating lymphoid cells. Am J Pathol. 1995; 147: 1152-60.

18. Yoshino K, Kishibe K, Nagato T, Ueda S, Komabayashi Y, Takahara M, Harabuchi Y. Expression of CD70 in nasal natural killer/T cell lymphoma cell lines and patients; its role for cell proliferation through binding to soluble CD27. Br J Haematol. 2013; 160: 331-42. doi: 10.1111/ bjh. 12136.

19. Diegmann J, Junker K, Gerstmayer B, Bosio A, Hindermann W, Rosenhahn J, von Eggeling F. Identification of CD70 as a diagnostic biomarker for clear cell renal cell carcinoma by gene expression profiling, real-time RT-PCR and immunohistochemistry. Eur J Cancer. 2005; 41: 1794-801. doi: 10.1016/j.ejca.2005.05.005.
20. Junker K, Hindermann W, von Eggeling F, Diegmann J, Haessler K, Schubert J. CD70: a new tumor specific biomarker for renal cell carcinoma. J Urol. 2005; 173: 2150-3. doi: 10.1097/01.ju.0000158121.49085.ba.

21. McEarchern JA, Oflazoglu E, Francisco L, McDonagh CF, Gordon KA, Stone I, Klussman K, Turcott E, van Rooijen N, Carter P, Grewal IS, Wahl AF, Law CL. Engineered anti-CD70 antibody with multiple effector functions exhibits in vitro and in vivo antitumor activities. Blood. 2007; 109: 1185-92. doi: 10.1182/blood-2006-07-034017.

22. Trebing J, El-Mesery M, Schafer V, Weisenberger D, Siegmund D, Silence K, Wajant H. CD70-restricted specific activation of TRAILR1 or TRAILR2 using scFv-targeted TRAIL mutants. Cell Death Dis. 2014; 5: e1035. doi: 10.1038/cddis.2013.555.

23. Wischhusen J, Jung G, Radovanovic I, Beier C, Steinbach JP, Rimner A, Huang H, Schulz JB, Ohgaki H, Aguzzi A, Rammensee HG, Weller M. Identification of CD70mediated apoptosis of immune effector cells as a novel immune escape pathway of human glioblastoma. Cancer Res. 2002; 62: 2592-9.

24. Silence K, Dreier T, Moshir M, Ulrichts P, Gabriels SM, Saunders M, Wajant H, Brouckaert P, Huyghe L, Van Hauwermeiren T, Thibault A, De Haard HJ. ARGX-110, a highly potent antibody targeting CD70, eliminates tumors via both enhanced ADCC and immune checkpoint blockade. MAbs. 2014; 6: 523-32. doi: 10.4161/mabs.27398.

25. McEarchern JA, Smith LM, McDonagh CF, Klussman K, Gordon KA, Morris-Tilden CA, Duniho S, Ryan M, Boursalian TE, Carter PJ, Grewal IS, Law CL. Preclinical characterization of SGN-70, a humanized antibody directed against CD70. Clin Cancer Res. 2008; 14: 7763-72. doi: 10.1158/1078-0432.CCR-08-0493.

26. Law CL, Gordon KA, Toki BE, Yamane AK, Hering MA, Cerveny CG, Petroziello JM, Ryan MC, Smith L, Simon R, Sauter G, Oflazoglu E, Doronina SO, et al. Lymphocyte activation antigen CD70 expressed by renal cell carcinoma is a potential therapeutic target for anti-CD70 antibodydrug conjugates. Cancer Res. 2006; 66: 2328-37. doi: 10.1158/0008-5472.CAN-05-2883.

27. McDonagh CF, Kim KM, Turcott E, Brown LL, Westendorf L, Feist T, Sussman D, Stone I, Anderson M, Miyamoto J, Lyon R, Alley SC, Gerber HP, et al. Engineered anti-CD70 antibody-drug conjugate with increased therapeutic index. Mol Cancer Ther. 2008; 7: 2913-23. doi: 10.1158/15357163.MCT-08-0295.

28. Oflazoglu E, Stone IJ, Gordon K, Wood CG, Repasky EA, Grewal IS, Law CL, Gerber HP. Potent anticarcinoma activity of the humanized anti-CD70 antibody h1F6 conjugated to the tubulin inhibitor auristatin via an uncleavable linker. Clin Cancer Res. 2008; 14: 6171-80. doi: 10.1158/1078-0432.CCR-08-0916.

29. Ryan MC, Kostner H, Gordon KA, Duniho S, Sutherland MK, Yu C, Kim KM, Nesterova A, Anderson M, McEarchern JA, Law CL, Smith LM. Targeting pancreatic 
and ovarian carcinomas using the auristatin-based anti-CD70 antibody-drug conjugate SGN-75. Br J Cancer. 2010; 103: 676-84. doi: 10.1038/sj.bjc.6605816.

30. Jeffrey SC, Burke PJ, Lyon RP, Meyer DW, Sussman D, Anderson M, Hunter JH, Leiske CI, Miyamoto JB, Nicholas ND, Okeley NM, Sanderson RJ, Stone IJ, et al. A potent anti-CD70 antibody-drug conjugate combining a dimeric pyrrolobenzodiazepine drug with site-specific conjugation technology. Bioconjug Chem. 2013; 24: 1256-63. doi: $10.1021 / \mathrm{bc} 400217 \mathrm{~g}$.

31. Owonikoko TK, Hussain A, Stadler WM, Smith DC, Kluger H, Molina AM, Gulati P, Shah A, Ahlers CM, Cardarelli PM, Cohen LJ. First-in-human multicenter phase I study of BMS-936561 (MDX-1203), an antibody-drug conjugate targeting CD70. Cancer Chemother Pharmacol. 2016; 77 : 155-62. doi: 10.1007/s00280-015-2909-2.

32. Eisenhauer EA, Therasse P, Bogaerts J, Schwartz LH, Sargent D, Ford R, Dancey J, Arbuck S, Gwyther S, Mooney M, Rubinstein L, Shankar L, Dodd L, et al. New response evaluation criteria in solid tumours: revised RECIST guideline (version 1.1). Eur J Cancer. 2009; 45: 228-47. doi: 10.1016/j.ejca.2008.10.026.

33. Mourad WF, Dutcher J, Ennis RD. State-of-the-art management of renal cell carcinoma. Am J Clin Oncol. 2014; 37: 498-505. doi: 10.1097/COC.0b013e31825d5522.

34. Mikami S, Oya M, Mizuno R, Kosaka T, Ishida M, Kuroda N, Nagashima Y, Katsube K, Okada Y. Recent advances in renal cell carcinoma from a pathological point of view. Pathol Int. 2016; 66: 481-90. doi: 10.1111/pin.12433.

35. Grassi P, Verzoni E, Ratta R, Mennitto A, de Braud F, Procopio G. Cabozantinib in the treatment of advanced renal cell carcinoma: design, development, and potential place in the therapy. Drug Des Devel Ther. 2016; 10: 2167 72. doi: 10.2147/DDDT.S104225.

36. Mennitto A, Grassi P, Ratta R, Verzoni E, Prisciandaro $\mathrm{M}$, Procopio G. Nivolumab in the treatment of advanced renal cell carcinoma: clinical trial evidence and experience. Ther Adv Urol. 2016; 8: 319-26. doi: $10.1177 / 1756287216656811$.

37. Tykodi SS. PD-1 as an emerging therapeutic target in renal cell carcinoma: current evidence. Onco Targets Ther. 2014; 7: 1349-59. doi: 10.2147/OTT.S48443.

38. Thevanayagam L, Bell A, Chakraborty I, Sufi B, Gangwar S, Zang A, Rangan V, Rao C, Wang Z, Pan C, Chong C, Cardarelli P, Deshpande S, et al. Novel detection of DNA-alkylated adducts of antibody-drug conjugates with potentially unique preclinical and biomarker applications. Bioanalysis. 2013; 5: 1073-81. doi: 10.4155/ bio.13.57.

39. Jacobs J, Deschoolmeester V, Zwaenepoel K, Rolfo C, Silence K, Rottey S, Lardon F, Smits E, Pauwels P. CD70: an emerging target in cancer immunotherapy. Pharmacol Ther. 2015; 155: 1-10. doi: 10.1016/j. pharmthera.2015.07.007.
40. Jacobs J, Zwaenepoel K, Rolfo C, Van den Bossche J, Deben C, Silence K, Hermans C, Smits E, Van Schil P, Lardon F, Deschoolmeester V, Pauwels P. Unlocking the potential of CD70 as a novel immunotherapeutic target for non-small cell lung cancer. Oncotarget. 2015; 6: 13462-75. doi: 10.18632/oncotarget.3880.

41. Friesen C, Roscher M, Hormann I, Leib O, Marx S, Moreno J, Miltner E. Anti-CD33-antibodies labelled with the alphaemitter Bismuth-213 kill CD33-positive acute myeloid leukaemia cells specifically by activation of caspases and break radio- and chemoresistance by inhibition of the antiapoptotic proteins $\mathrm{X}$-linked inhibitor of apoptosis protein and B-cell lymphoma-extra large. Eur J Cancer. 2013; 49: 2542-54. doi: 10.1016/j.ejca.2013.04.008.

42. Maeda H, Nakamura H, Fang J. The EPR effect for macromolecular drug delivery to solid tumors: Improvement of tumor uptake, lowering of systemic toxicity, and distinct tumor imaging in vivo. Adv Drug Deliv Rev. 2013; 65: 71-9. doi: 10.1016/j.addr.2012.10.002.

43. Matsumura Y, Maeda H. A new concept for macromolecular therapeutics in cancer chemotherapy: mechanism of tumoritropic accumulation of proteins and the antitumor agent smancs. Cancer Res. 1986; 46: 6387-92.

44. Dahle J, Jonasdottir TJ, Heyerdahl H, Nesland JM, Borrebaek J, Hjelmerud AK, Larsen RH. Assessment of long-term radiotoxicity after treatment with the low-doserate alpha-particle-emitting radioimmunoconjugate (227) Th-rituximab. Eur J Nucl Med Mol Imaging. 2010; 37: 93-102. doi: 10.1007/s00259-009-1197-7.

45. Reincke U, Mellmann J, Goldmann E. Variations in radioresistance of rats during the period of growth. Int $\mathrm{J}$ Radiat Biol Relat Stud Phys Chem Med. 1967; 13: 137-46.

46. Koenig KL, Goans RE, Hatchett RJ, Mettler FA Jr, Schumacher TA, Noji EK, Jarrett DG. Medical treatment of radiological casualties: current concepts. Ann Emerg Med. 2005; 45: 643-52. doi: 10.1016/j. annemergmed.2005.01.020.

47. Yoshida T, Jin K, Song H, Park S, Huso DL, Zhang Z, Liangfeng $\mathrm{H}$, Zhu $\mathrm{C}$, Bruchertseifer $\mathrm{F}$, Morgenstern A, Sgouros G, Sukumar S. Effective treatment of ductal carcinoma in situ with a HER-2- targeted alpha-particle emitting radionuclide in a preclinical model of human breast cancer. Oncotarget. 2016; 7: 33306-15. doi: 10.18632/ oncotarget.8949.

48. Dahle J, Borrebaek J, Melhus KB, Bruland OS, Salberg G, Olsen DR, Larsen RH. Initial evaluation of (227)Th-pbenzyl-DOTA-rituximab for low-dose rate alpha-particle radioimmunotherapy. Nucl Med Biol. 2006; 33: 271-9. doi: 10.1016/j.nucmedbio.2005.12.004.

49. Reddy N, Ong GL, Behr TM, Sharkey RM, Goldenberg DM, Mattes MJ. Rapid blood clearance of mouse IgG2a and human IgG1 in many nude and $\mathrm{nu} /+$ mouse strains is due to low IgG2a serum concentrations. Cancer Immunol Immunother. 1998; 46: 25-33. 